\title{
Recruitment and abundance estimation of glass eel genus Anguilla in three large estuaries on the coast of Sukabumi West Java
}

\author{
Triyanto ${ }^{1, *}$, Gadis Sri Haryani ${ }^{1}$, Mohammad Mukhlis Kamal $^{2}$, Iwan Ridwansyah ${ }^{1}$, Fauzan \\ Ali $^{1}$, Aldiano Rahmadya ${ }^{1}$, Mohamad Anwar ${ }^{1}$, Eva Nafisyah $^{1}$ \\ ${ }^{1}$ Research Center for Limnology, National Research and Innovation Agency (BRIN) \\ ${ }^{2}$ Faculty of Fisheries and Marine Sciences IPB University, Indonesia
}

\begin{abstract}
The rivers on the Sukabumi Coast flow into the Indian Ocean. Three major rivers, namely the Cimandiri River, Cikaso River, and Cibuni River, are sources of glass eel fishing. This study aims to determine the recruitment and estimate of glass eel abundance for future glass eel management. The study was conducted from November 2020-April 2021. Estimation of glass eel abundance was carried out using a fyke net. The glass eel calculation is determined based on the number of glass eels caught, the water discharge entering the fyke net, the water discharge in the estuary, and other variables. The results showed that glass eel recruitment began at the beginning of the rainy season in November 2020 and lasted at the end of the study in April 2021. Anguilla bicolor bicolor is a dominant species of glass eel found in the three river estuaries. The estimated abundance of glass eel was approximately $2,583,438-13,556,650$ ind./year or $326,24-1,812 \mathrm{~kg} / \mathrm{year}$. The abundance of glass eels at the estuary of Cimandiri River was higher than that of the estuary of Cibuni River and the estuary of Cikaso River.
\end{abstract}

\section{Introduction}

Sukabumi coastal waters are located in the southern part of the island of West Java, directly adjacent to the Indian Ocean. The river estuary on the Sukabumi coast has been known as a glass eel fishing area $[1,2,3]$ as the river of Cimandiri is one of the potential areas for fishing glass eels $[3,4,5]$. Catching glass eel has become one of the livelihoods of the local community. The financial esteem of glass eel makes this product the essential target for fishing.

The glass eel is a juvenile freshwater eel genus Anguilla. Glass eel has a transparent body color like glass. The body shape is elongated with a total body length of 50-70 mm. Glass eel is the final stage of eel larvae. The eel larvae live in the sea. The shape is like broad leaves, translucent, known as leptocephalus [6,7]. Eel larvae live in ocean waters, and ocean currents influence their movements. Leptocephalus lives as plankton carried by sea streams drawing closer coastal zones [8]. Leptocephalus undergoes metamorphosis into

\footnotetext{
* Corresponding author: triyanto@limnologi.lipi.go.id
} 
a glass eel. It will migrate to inland water through rivers to arise into yellow eels and silver eels.

According to a Fisheries Service of Sukabumi Regency report, the production of glass eel catches in 2014 reached 1,952 tons [9]. The maximum sustainable catch of glass eel at the mouth of the Cimandiri River is $991.20 \mathrm{~kg} / \mathrm{year}$., while the average actual catch in 2014-2018 is $725.55 \mathrm{~kg} /$ year [3]. Institutional recording of data on eel and glass eel catches is limited. Existing data is not available continuously. It is one of the obstacles in eel resource management that needs to be overcome [9]. Sources of glass eel on the Sukabumi coast are found in several rivers that flow into the Indian Ocean. The results of several studies indicate that all rivers in Sukabumi Regency that flow into the Indian Ocean are migration areas of the glass eel $[2,10]$. The abundance of glass eels in each of these rivers fluctuates depending on the rainy and dry seasons [2].

Information on glass eel recruitment and abundance is essential to know. This information helps determine eel cultivation activities. Currently, the cultivation of eels still depends on glass eels caught in nature. The current availability of eel seeds cannot be produced from glass eel production activities from the artificial spawning process [11]. This study aimed to determine the recruitment and estimation of glass eel abundance in the three largest rivers on the Sukabumi coast.

\section{Methods}

\subsection{Location, research time, and sampling procedures.}

Research activities were carried out in river estuaries on the southern coast of West Java, namely the Cimandiri, Cikaso, and Cibuni River Estuaries (Figure 1). The study was carried out in November 2020-April 2021. The glass eels were captured using a fyke net in the new moon phase (Figure 2). The fishing was done between 19:00 and 00:00 pm. The captured glass eels were collected to be counted and weighed to obtain data on their abundance. As much as $10 \%$ of the catch was preserved with $95 \%$ alcohol preservative for identification purposes. Identification is made based on the morphometric character [12]. The morphometric measurement of the glass eel was based on the measurement criteria [10, 13], as shown in Figure 3.

\subsection{Data analysis}

\subsubsection{Glass eel abundance}

The abundance of glass eels was determined by the number of glass eels caught using fyke nets. The formula for estimating the abundance and biomass of glass eel is primarily based totally on the following calculations:

- Determination of the fishing area

$$
L=p * l * t
$$

$L$ is the volume of the fishing area $\left(\mathrm{m}^{3}\right) ; p$ is the length of the fyke net $(\mathrm{m}) ; l$ is the width of the fyke net (m), and $t$ is the height of the fyke net (m). 


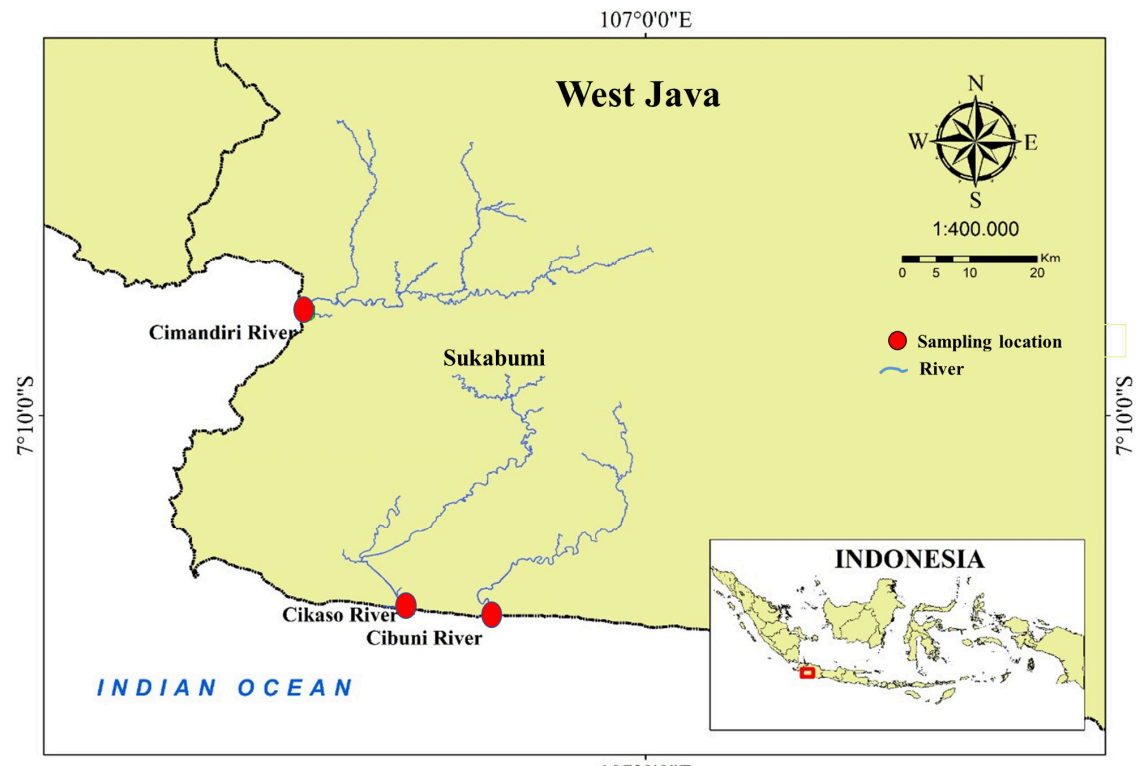

$107^{\circ} 0^{\prime} 0^{\prime \prime} \mathrm{E}$

Fig. 1. Research location at the Coast of Sukabumi West Java.

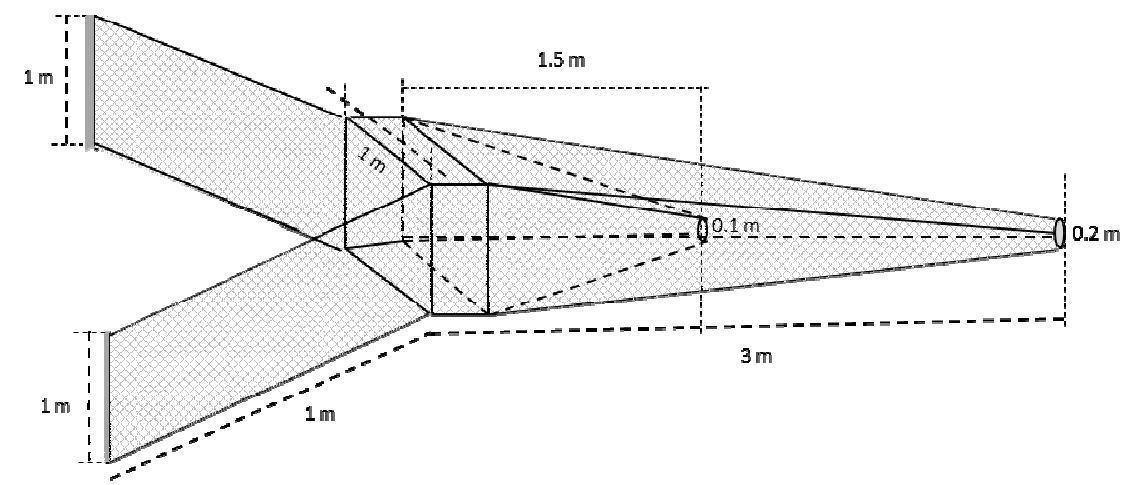

Fig. 2. Dimensions of a fyke net for catching glass eels.

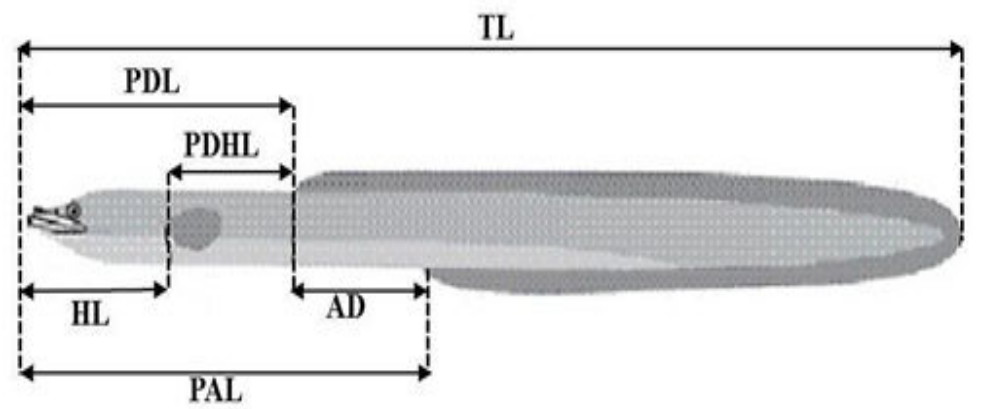

Fig. 3. Eel morphometric measurements. $T L$ : total length; $H L$ : head length; $P D H L$ : predorsal head length; $P A L$ : pre-anal length; $P D L$ : pre-dorsal length; and $A D$ : anodorsal length. 
- Estimation abundance of glass eels

$$
A=N / L
$$

$A$ is the number of glass eels (ind. $\left./ \mathrm{m}^{3}\right) ; N$ is caught of glass eel, and $L$ is the volume of the fishing area $\left(\mathrm{m}^{3}\right)$.

- Biomass of glass eels

$$
B=A * \hat{w} / 1000
$$

$B$ is the biomass of glass eel $(\mathrm{kg}) . A$ is the number of glass eels (ind. $/ \mathrm{m}^{3}$ ), and $\hat{w}$ is the average weight of glass eel (g/Ind.).

- Estimation abundance of glass eels

$$
\begin{aligned}
G e_{n} & ={\frac{N}{\left(p * l * t * X_{i}^{*} a\right)}}^{*}\left(Y_{i}^{*} Z_{i} * b * c * d * e\right) \\
G e_{b} & ={\frac{N}{\left(p * l * t * X_{i}^{*} a\right)}}^{*}\left(Y_{i}^{*} Z_{i} * b * c * d * e\right) * R_{i}
\end{aligned}
$$

\begin{tabular}{|c|c|}
\hline Variables & Value \\
\hline $\begin{array}{l}\text { Estuary of Cimandiri River } \\
X_{1}: \text { Water discharge in fish gear }\left(\mathrm{m}^{3} / \mathrm{S}\right) \\
Y_{1}: \text { Water flow }(\mathrm{m} / \mathrm{S}) \\
Z_{1}: \text { Depth }(\mathrm{m}) \\
\text { River width }(\mathrm{m})\end{array}$ & $\begin{array}{r}0.041-0.252 \\
0.361 \\
1.5 \\
104\end{array}$ \\
\hline $\begin{array}{l}\text { Estuary of Cikaso River } \\
X_{2}: \text { Water discharge in fish gear }\left(\mathrm{m}^{3} / \mathrm{S}\right) \\
Y_{2}: \text { Water flow }(\mathrm{m} / \mathrm{S}) \\
Z_{2}: \text { Depth }(\mathrm{m}) \\
\text { River width }(\mathrm{m})\end{array}$ & $\begin{array}{r}0.04-0.147 \\
0.426 \\
2 \\
218 \\
\end{array}$ \\
\hline $\begin{array}{l}\text { Estuary of Cibuni River } \\
X_{3}: \text { Water discharge in fish gear }\left(\mathrm{m}^{3} / \mathrm{S}\right) \\
Y_{3}: \text { Water flow }(\mathrm{m} / \mathrm{S}) \\
Z_{3}: \text { Depth }(\mathrm{m}) \\
\text { River width }(\mathrm{m}) \\
\end{array}$ & $\begin{array}{r}0.05-0.376 \\
0.214 \\
1.5 \\
135 \\
\end{array}$ \\
\hline $\begin{array}{l}\text { Fishing variable } \\
\text { (a) Fishing time (hours) } \\
\text { (b) River width through which the glass eel passes (m) } \\
\text { (c) Migration time in } 1 \text { day (hours) } \\
\text { (d) Migration time in } 1 \text { month (days) } \\
\text { (e) Number of months in 1 year of migration (months) }\end{array}$ & $\begin{array}{r}4 \\
30 \\
12 \\
5 \\
6\end{array}$ \\
\hline $\begin{array}{l}\text { The average weight of glass eel } \\
R_{1} \text { : Average weight of glass eel in the Cimandiri }(\mathrm{g}) \\
R_{2} \text { : Average weight of glass eel in Cikaso }(\mathrm{g}) \\
R_{3} \text { : Average weight of glass eel in Cibuni }(\mathrm{g})\end{array}$ & $\begin{array}{l}0.136 \\
0.126 \\
0.136\end{array}$ \\
\hline
\end{tabular}

$G e_{n}$ is the estimated number of glass eels (glass eel/year); $\mathbf{G} e_{b}$ estimates biomass of glass eel (kg/year). $R i ; X_{1} ; Y i ; Z i$ and $a ; b ; c ; d ; e$ is the variable used in the calculation (Table 1).

Table 1. Variables used in the calculation of the estimated abundance of glass eel. 


\section{Results and Discussion}

\subsection{Recruitment of glass eel}

The recruitment of glass eels in 2020 is changing times. Based on observations and interviews with fishers, the catch of glass eel in the Cimandiri River in 2020 was found at the beginning of the year, namely January-February 2020, but in small numbers. In MarchOctober 2020, fishers no longer carry out fishing activities. It is because glass eels are present in small quantities and are not economical when caught. The low abundance of glass eels at the beginning of the year until October 2010 is thought to be due to the changes at the start of the rainy season. The intensity of the rain starts to be high in November 2020. The amount of glass eel abundance during recruitment fluctuates and varies from year to year. Factors that distinguish the abundance of glass eels include the time of the rainy season, ocean currents, water discharge of the river, and local environmental factors such as turbidity in the estuary, local rainfall, and water temperature [14].

Recruitment of glass eels entering the Sukabumi coastal estuary will begin in November 2020. Research on glass eel recruitment has been carried out at the mouth of the Cimandiri River [15]. It was explained that eel recruitment correlated with spawning time and eel spawning time in the rainy season. The recruitment of glass eels on the Cimandiri River in 2018 occurred throughout the year with two peak recruitment periods. The first peak occurred in April 2018, and the second peak in August 2018 [15]. In this study, a similar pattern was seen where many glass eels were caught in March-April 2021.

The identification of glass eel species based on morphometric (AD/TL)\% [12]. The glass eel found in November 2020-April 2021 in three river estuaries consisted of three species. It was Anguilla bicolor bicolor, Anguilla nebulosa nebulosa, and Anguilla marmorata. The characters (AD/TL)\% of glass eel found for A. bicolor bicolor ranged from 0-4.0\%, A. nebulosa nebulosa 7.02-13.73\%, and Anguilla marmorata 14.0-18.75\%. Glass eel $A$. bicolor bicolor was found as much as $85.75 \%$, then $A$. nebulosa nebulosa $12.93 \%$, and $A$. marmorata $1.32 \%$. (Figure 4). The results of previous studies stated similar results where three types of glass eel were found in the Cimandiri River, namely $A$. bicolor bicolor (90.53\%), A. marmorata (4.46\%), and A. nebulosa nebulosa (5.02\%) with A. bicolor bicolor as the dominant species [15]. Another study also obtained the same results; the results of his research obtained glass eels of A. bicolor bicolor $71.69 \%$, A. marmorata $21.69 \%$, and $A$. nebulosa nebulosa $6.60 \%$ [10]. Unfortunately, no studies have reported the species composition of the glass eel from the Cikaso and Cibuni Rivers estuary.

The glass eel recruitment in 2020 underwent a significant change. Glass eel began to enter estuary waters in the Sukabumi coastal area in November 2020. Glass eel data collection conducted from November 2020 to April 2021 showed variations in the total length of the glass eel between $42-69 \mathrm{~mm}$ and a weight of 0.04-0.27 g/individuals $(\mathrm{N}=2274)$. The total length of the glass eel entering the Cimandiri River estuary was 46-60 $\mathrm{mm}(\mathrm{N}=240)$, at the Cikaso River estuary was $42-67 \mathrm{~mm}(\mathrm{~N}=1164)$, and at the Cibuni River estuary was 44-69 $\mathrm{mm}(\mathrm{N}=1435)$. There is no significant difference in the glass eel size of the three river estuaries (Figure 5). While the weight of the glass eel at the Cimandiri River estuary was $0.05-0.22 \mathrm{~g} / \mathrm{Ind}$, the Cikaso River estuary was $0.05-0.26$ $\mathrm{g} /$ Ind. Cibuni River estuary was $0.04-0.27 \mathrm{~g} / \mathrm{Ind}$. The total length of the glass eel caught in the 2017-2018 period at the mouth of the Cimandiri River was 40-65 mm, with a body weight ranging from $0.030-0.23 \mathrm{~g}$ [15]. Meanwhile, the results of another study [16] at the mouth of the Cimandiri River found that the dominant total length of glass eel was 51.57$53.27 \mathrm{~mm}$. Glass eel (A. bicolor bicolor) from the Cibaliung River in Banten has a total 
length of $53.01 \pm 1.75 \mathrm{~mm}$ [17]. The size of the glass eel from the Cikaso and Cibuni rivers has not been obtained by information from previous studies.

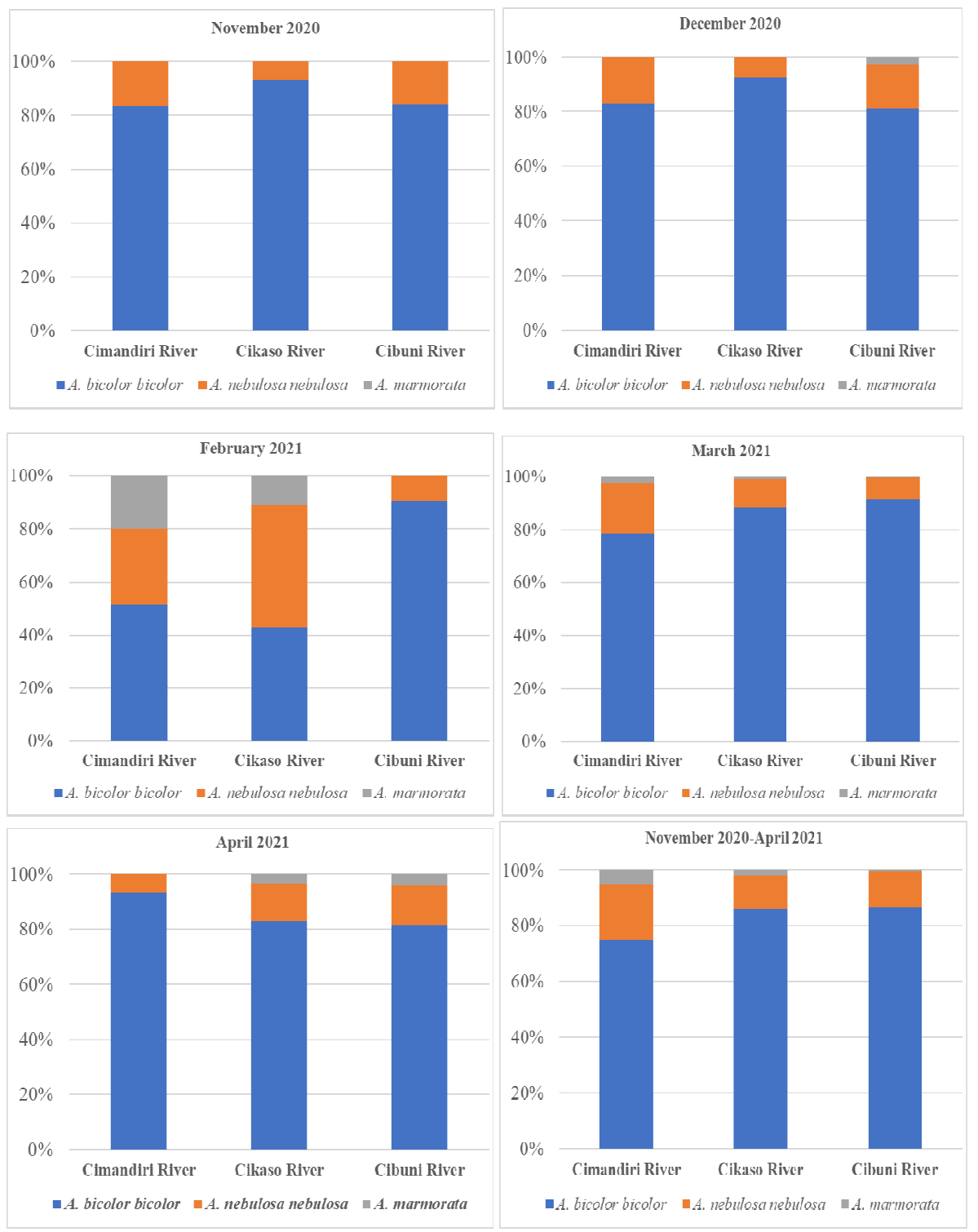

Fig. 4. Species composition of glass eel at the three rivers in Sukabumi, November 2020April 2021. 

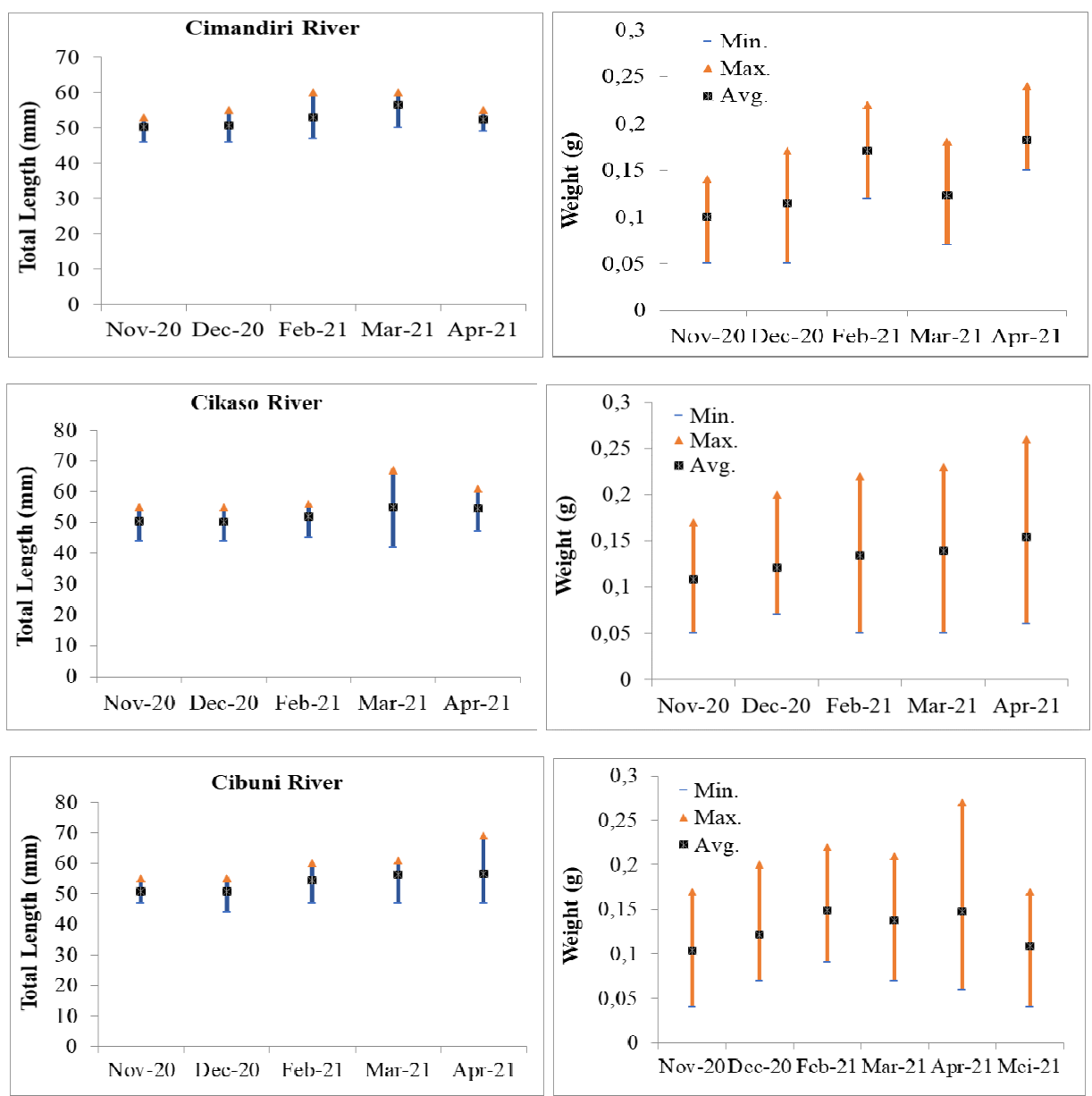

Fig. 5. The size of the glass eel at the three rivers in Sukabumi, November 2020-April 2021.

\subsection{Estimation of glass eel abundance}

The estimation of glass eel abundance in three river estuaries in Sukabumi got different abundance results. In the Cimandiri River estuary, the average abundance of glass eels reaches $2,259,442$ Ind./month or $302 \mathrm{~kg} /$ month. Where abundance in one year estimated $13,556,650 \mathrm{ind}$./year or $1,812 \mathrm{~kg} /$ year. The estimated average abundance of glass eels in the Cikaso River estuary was 430,573 Ind./month or $54 \mathrm{~kg} /$ month. The abundance in one year was estimated at 2,583,438 Ind./year or $326.24 \mathrm{~kg} /$ year. The estimated average abundance of glass eels in the Cibuni River estuary was 962,842 ind./month or $131 \mathrm{~kg} / \mathrm{month}$. The abundance in one year is estimated at 5,777,053 ind./year or $785.57 \mathrm{~kg} /$ year (Table 1). Rivers in the southern part of West Java are eel distribution areas in the southern part of Java Island. According to research [2], rivers in the South of West Java are migration areas of eels, the abundance of glass eels entering these rivers' estuary has fluctuated. 
Table 1. Estimation abundance of glass eel with fyke net in December 2020-April 2021.

\begin{tabular}{|c|c|c|c|c|}
\hline Time (month) & & $\begin{array}{l}\text { Cimandiri } \\
\text { River }\end{array}$ & $\begin{array}{l}\text { Cikaso } \\
\text { River }\end{array}$ & $\begin{array}{l}\text { Cibuni } \\
\text { River }\end{array}$ \\
\hline $\begin{array}{l}\text { December } 2020 \\
\text { Estimation of } \\
\text { abundance }\end{array}$ & $\begin{array}{l}\text { Amount (Ind.) } \\
\text { Weight (kg) }\end{array}$ & $\begin{array}{r}541,070 \\
73.83\end{array}$ & $\begin{array}{r}280,265 \\
35.39\end{array}$ & $\begin{array}{r}147,421 \\
20.05\end{array}$ \\
\hline $\begin{array}{l}\text { February } 2021 \\
\text { Estimation of } \\
\text { abundance }\end{array}$ & $\begin{array}{l}\text { Amount (Ind.) } \\
\text { Weight (kg) }\end{array}$ & $\begin{array}{r}2,102,605 \\
287 \\
\end{array}$ & $\begin{array}{r}259,444 \\
32.76 \\
\end{array}$ & $\begin{array}{r}274,243 \\
37.29 \\
\end{array}$ \\
\hline $\begin{array}{l}\text { March } 2021 \\
\text { Estimation of } \\
\text { abundance }\end{array}$ & $\begin{array}{l}\text { Amount (Ind.) } \\
\text { Weight (kg) }\end{array}$ & $\begin{array}{r}4,953,098 \\
664.18 \\
\end{array}$ & $\begin{array}{r}740,902 \\
93.56 \\
\end{array}$ & $\begin{array}{r}2,849,956 \\
387.54 \\
\end{array}$ \\
\hline $\begin{array}{l}\text { April } 2021 \\
\text { Estimation of } \\
\text { abundance }\end{array}$ & $\begin{array}{l}\text { Amount (Ind.) } \\
\text { Weight (kg) }\end{array}$ & $\begin{array}{r}1,440,994 \\
183.09 \\
\end{array}$ & $\begin{array}{r}441,681 \\
55.78 \\
\end{array}$ & $\begin{array}{r}579,749 \\
78.83 \\
\end{array}$ \\
\hline $\begin{array}{l}\text { Average } \\
\text { Estimation of } \\
\text { abundance }\end{array}$ & $\begin{array}{l}\text { Amount (Ind.) } \\
\text { Weight (kg) }\end{array}$ & $\begin{array}{r}2,259,442 \\
302\end{array}$ & $\begin{array}{r}430,573 \\
54\end{array}$ & $\begin{array}{r}962,842 \\
131\end{array}$ \\
\hline $\begin{array}{l}\text { Abundance } \\
\text { Estimation in } \\
\text { a year }\end{array}$ & $\begin{array}{l}\text { Amount (Ind.) } \\
\text { Weight (kg) }\end{array}$ & $\begin{array}{r}13,556,650 \\
1,812\end{array}$ & $\begin{array}{r}2,583,438 \\
326.24\end{array}$ & $\begin{array}{r}5,777,053 \\
785.57\end{array}$ \\
\hline
\end{tabular}

The difference in the abundance of glass eels migrating to the three estuary areas is related to several factors, such as the cross-sectional area of the river mouth, river discharge, water currents, and tides that occur in these locations. The broader the crosssection of the estuary, the more flexible the migration of glass eels to freshwater through the estuary. The mouths of the Cikaso and Cibuni rivers are located directly adjacent to the Indian Ocean. The dynamics of changing the shape of the river mouth due to river water discharge, waves, and currents sometimes cause changes in river mouth openings. At specific periods, the estuary is closed by sandbars that form in front of the estuary. This phenomenon usually occurs in the dry season, when river water flowing into the sea is low. Local people call it the term "bugel". According to oceanographers, this phenomenon is known as temporary open/close estuaries (TOCEs) [18;19]. It can affect the glass eel recruitment process to estuarine and freshwaters. According to [20], the glass eel mechanism enters estuary waters and freshwater by utilizing tidal flow using selective tidal stream transport.

\section{Conclusions}

Recruitment of glass eels withinside the tree estuaries in Sukabumi passed off at the start of the wet season in November 2020. The highest recruitment takes place in March-April 2021. The species of glass eels found in three river estuaries were A. bicolor bicolor, $A$. nebulosa nebulosa, and A. marmorata. The dominant species that was found was A.bicolor bicolor. The estimated abundance of glass eels approximately 2,583,438-13,556,650 ind./year or 326.24-1,812 kg/year. The abundance of glass eel in the estuary of Cimandiri River is higher than that of the estuary of Cibuni River and the estuary of Cikaso River. 


\section{Acknowledgments}

This research was supported by the National Research Priority, National Research and Innovation Agency Republic of Indonesia 2020. We thank the fisherman of glass eel in Cimandiri River, Cikaso River, and Cibuni River Sukabumi West Java and all parties involved and participated in the research.

\section{Author contributions}

T, GSH, and MMK are the main contributors to this paper. All other authors contributed equally to this publication.

\section{References}

1. A.A. Hakim, M.M Kamal, N.A Butet, R. Affandi, IOP Conf. Ser. Earth and Environ. Sci. 404 (2019)

2. Haryono, G. Wahyudewantoro, Omni-Akuatika 12, 3 (2016)

3 Triyanto, R. Affandi, M.M Kamal, G.S. Haryani, IOP Conf. Ser. Earth and Environ. Sci 535 (2020)

4 M.R Fahmi, R. Himawati, FITA, 1-8 (2010)

5 Haryono, J. Subagja, G. Wahyudewantoro, Proc. Natl. Fish Semin. 6, 251-259 (2010)

6 F.W Tesch, The Eel Biology and Management of Anguilids Eels (London, Chapman and Hall, 1977)

7 N. Mochioka, Leptocephali, In K. Aida., K. Tsukamoto., K. Yamauchi, Eel Biology (Tokyo, Springer, 2003)

8 N. Bru, P. Prouzet, M. Lejeune, Aquat. Living Resour. 22, 4 (2009)

9 S. Honda, D. Muthmainnah, N. Suryati, D. Oktaviani, S. Siriraksophon, T. Amornpiyakrit, BI Prisantosol, Mar. Res. Indonesia 41, 1 (2016)

10 A.A. Hakim, M.M. Kamal, N.A. Butet, R. Affandi, JITKT 7, 2 (2015)

11 A. Okamura, N. Horie, N. Mikawa, Y. Yamada, K. Tsukamoto, Ecol. Freshw. Fish 23, 1 (2014)

12 E. Reveillac, P.A. Gagnaire, L. Finigers, P. Berrebi, T. Robinet, Valade, E Feunteun, J. Fish Biol. 25, 547-572 (2009)

13 O. Tabeta, T. Takai, I. Matsui, J Ichthyol. 22, 4 (1976)

14 C. Arribas, C.F. Delgado, F.J.O. Patrena, P. Drak,. Estuar. Coast. Shelf Sci. 107, 46-57 (2012)

15 Triyanto, R. Affandi, M.M. Kamal, G.S. Haryani, AACL Bioflux 13, 2 (2020)

16 Sriati, Proc. Natl. Forum Trop. Eel Fish. Res. 59-63 (2003)

17 H.Y. Sugeha, M.U. Genisa, OLDI 41, 1 (2015)

18 A.K. Whitfield, South. Afr. J. Aquat. Sci. 8, 1-2 (1992)

19 L.R.D. Human, G.C. Snow, J.B. Adams, S. Afr. J. Bot. 107, 39-48 (2016)

20 A. Cresci, M.D. Caroline, B.P. Claire, D.S. Steven, B.S. Anne, I.B. Howard, Commun. Biol. 2, 366 (2019) 